\title{
Apoptosis Induction of Cervical Carcinoma HeLa Cells Line by Dichloromethane Fraction of the Rinds of Garcinia cowa Roxb
}

\author{
Fatma Sri Wahyuni', Siska Febria', Dessy Arisanty ${ }^{2}$
}

Fatma Sri Wahyuni ${ }^{1 *}$, Siska Febria', Dessy Arisanty ${ }^{2}$

${ }^{1}$ Faculty of Pharmacy, Andalas University, Padang, West Sumatra, INDONESIA.

${ }^{2}$ Faculty of Medicine, Andalas University, Padang, West Sumatra, INDONESIA.

\section{Correspondence}

Fatma Sri Wahyuni,

Faculty of Pharmacy, Andalas University, Kampus Limau Manis, Padang, West Sumatra, INDONESIA.

Mobile phone: +6281374024514

E-mail: fatmasriwahyuni@gmail.com

History

- Submission Date: 24-12-2016;

- Review completed: 05-01-2017.

- Accepted Date: 16-03-2017

DOI : 10.5530/pj.2017.4.76

Article Available online

http://www.phcogj.com/v9/i4

\section{Copyright}

(C) 2017 Phcog.Net. This is an openaccess article distributed under the terms of the Creative Commons Attribution 4.0 International license.

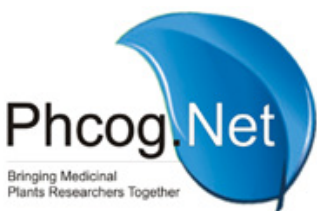

\begin{abstract}
Objective: This study aims to determine the apoptosis induction of HeLa cervical carcinoma cells death by dichloromethane fraction of the rinds of Garcinia cowa Roxb. Methods: Apoptosis induction of HeLa cell line was observed using a double staining method. Results: The result of double staining observation showed that an apoptosis occurs which marked with yellowish green fluorescence and cell fragmentation. The average percentage of apoptotic cells was higher in the treated variables $(70.38 \%)$ compared to the control variables $(12.26 \%$ ). Statistical analysis by Independent Sample T-Test showed apoptosis Sig. (2-tailed) $=0.000$ $(<0.025)$. Conclusion: The dichloromethane fraction of $G$. cowa rind induces apoptosis in HeLa cervical cancer cells.
\end{abstract}

Key words: Garcinia cowa Roxb., Apoptosis induction, HeLa cell line, Double stanining, Carcinoma cells.

\section{INTRODUCTION}

Cancer is one among the leading causes of death in worldwide. Cervical cancer is the second most common cancer in women worldwide, but it is the leading malignancy among women in many developing countries. The death rate of cervical cancer is highest in developing countries, especially Indonesia, which ranks second, while in worldwide it ranks fourth. ${ }^{1}$

Cancer cells have distinctive properties that are able to avoid the mechanism of apoptosis or programmed cell death mechanism. Apoptosis is an active cell suicide controlled by a network of genes and is an important process throughout growth as well as playing a key role in the pathogenesis of diseases including cancer. ${ }^{2}$ Apoptosis process has an important role in preventing uncontrolled cell growth. There are at least two communication pathways that are involved in apoptosis, the extrinsic and the intrinsic pathway. The extrinsic route is activated by ligand-bound death receptors of the tumor necrosis factor (TNF) receptor group. The intrinsic route is a signal transduction pathway involving the mitochondria and the Bcl-2 group. ${ }^{3}$

Treatment of cancer generally still relies on chemotherapy, a treatment using cytotoxic which has the effect of inhibiting or kill cancer cells. However, it does not only affect target cells (cancer cells) but also affect normal cells around it. ${ }^{4}$ To overcome these problems, a research is needed to find a new anticancer drug that have a selective work against cancer cells without damaging normal cells, especially those derived from natural materials.
Asam kandis (Garcinia cowa Roxb.) is known to contain xanthones in almost all parts of it, that show a strong cytotoxic effect that can be used as a potential new cytotoxic agents. ${ }^{5,6} \mathrm{G}$. cowa is potential as chemopreventive agents have been studied in vitro against various types of cancer cells, such as HL-60 (leukemia), MCF-7 (breast), DU-45 (prostate), NCI-H460 (NSCL) and T47D (breast). ${ }^{7-10}$

A preliminary study showed that dichloromethane (DCM) fraction from the rinds of G. cowa is known to have a cytotoxic effect on HeLa cervical cancer cells with $\mathrm{IC}_{50}$ value of $5.764 \mu \mathrm{g} / \mathrm{mL}$. Through this study, the apoptosis induction of HeLa cervical cancer cell death by DCM fraction of the rinds of G. cowa are studied further to develop cancer therapies, especially herbal medicine. The results of this study are expected to increase the potential and value of G. cowa. as a new anticancer with specific action.

\section{EXPERIMENTAL SECTION}

\section{Chemicals and Reagents}

Chemicals and reagents were all of analytical grade.

\section{Extraction}

Fresh rinds of Garcinia cowa were collected from from Batu Busuk, Padang, West Sumatra, Indonesia in August, 2015 then chopped into small pieces, air-dried at room temperature for 10 days to a constant weight and subsequently pulverized into fine powder. The powdered sample (500 g) was suspended in 4 liters of $70 \%$ ethanol for 24 hrs. The mixture obtained was filtered (with Whatman No. 1 fil-

Cite this article: Wahyuni FS, Febria S, Arisanty D. Apoptosis Induction of Cervical Carcinoma HeLa Cells Line by Dichloromethane Fraction of the Rinds of Garcinia cowa Roxb. Pharmacogn J. 2017;9(4):475-8. 
ter paper) and the resulting filtrate was concentrated with a rortary evaporator $\left(40^{\circ} \mathrm{C}\right)$. Thereafter, the product was lyophilized and extracted with dichloromethane to give $7.0 \mathrm{~g}$ of the residue, corresponding to a yield of $1.3 \%$. This was then stored in a dessicator for further use.

\section{Experimental Design \\ Cell Culture}

Cancer cells were removed from the freezer $\left(-80^{\circ} \mathrm{C}\right)$, warmed in a water bath at a temperature of $37^{\circ} \mathrm{C}$ for $2-3$ minutes. After the that, the cells were transferred into a flask which already contains $8 \mathrm{ml}$ of culture media RPMI-1640, incubated for 3-4 hours at a temperature of $37^{\circ} \mathrm{C}, 5 \%$ $\mathrm{CO}_{2}$, and then observed under a microscope to see if the cell is attached at the bottom of the flask and form a monolayer. Growth medium was replaced once in two days and when the number of cells in the flask reached $70-85 \%$, do sub-culture cells. Medium disposed of in the flask, then add 2-3 ml trypsin-EDTA and stir gently, incubation for 5-10 minutes at a temperature of $37^{\circ} \mathrm{C}, 5 \% \mathrm{CO}_{2}$, then observe the cells under a microscope. Cells that are ready to be used will be separated from the colony. Then the trypsin-EDTA solution containing the cells were centrifuged at a speed of $1500 \mathrm{rpm}$ for 5 minutes. Discard supernatant and the pellet was suspended in $2 \mathrm{ml}$ of medium. Enter into a new flask, stir gently. Incubation at a temperature of $37^{\circ} \mathrm{C}, 5 \% \mathrm{CO}_{2}$. At the end of incubation, add $2 \mathrm{ml}$ of trypsin-EDTA into the flask containing the cell culture, incubation again for 5-10 minute. Then the trypsin-EDTA solution containing the cells were centrifuged at a speed of $1500 \mathrm{rpm}$ for 5 minutes. Discard supernatant and the pellet resuspended in $1 \mathrm{ml}$ of RPMI medium. Take $10 \mu \mathrm{L}$ of cell suspension, put in haemocytometer cell counting. Do it under a microscope and counting the average number of cells is determined to make a cell suspension, ie 50.000 cells in a 24 well plate for observation of apoptosis.

\section{Observation of Apoptosis}

Apoptosis was detected by double staining method using ethidium bromide (EtBr) and acridine orange (AO). Coverslips were planted into a 24 -well plate and the cells with a density of $5 \times 10^{4}$ cells $/ \mathrm{mL}$ are distributed thereon. Then performed incubation at $37^{\circ} \mathrm{C}$ for 48 hours in a $5 \% \mathrm{CO} 2$ incubator. Subsequently added to the test solution with a concentration of $6 \mu \mathrm{g} / \mathrm{mL}$ and incubated again for 24 hours. At the end of incubation, the culture medium was taken. Coverslips containing cells removed, then placed on a glass object. Then, on the coverslip is added EtBr-AO Working Solution. Furthermore, the cover slip readily observed under the microscope fluorescence.

\section{RESULTS}

\section{Observation of Apoptosis}

A fluorescence color differences were seen between living cells and cells undergoing death by apoptosis and necrosis when observed under a narrow band fluorescein (FITC) filter (520-560 nm). Viable cells (live) have a uniform green fluorescence (Figure 1). Cells undergoing apoptosis death fluoresces yellowish green with rounded cell shape and fragmented, whereas cells undergoing necrosis death fluoresces orangered with crushed cell morphology (Figure 2) ${ }^{11}$ Each of these living cells, apoptosis and necrosis are calculated. The average percentage of apoptotic cells was higher in treatment variables $(70.38 \%)$ compared to the control variables (12.26\%).

The data results tested using the Independent Sample T-Test as follows:

1. The homogeneity of variance by Levene's Test for Equality of Variances obtained the value of viable cells with Sig. $=0.167$ ( $p>0.05)$, apoptotic cells with Sig. $=0.582(\mathrm{p}>0.05)$, necrosis cells with Sig. $=0.076$ ( $\mathrm{p}>0.05)$, and Bcl-2 gene expression with Sig. $=0.712(\mathrm{p}>0.05)$. This suggests that each of the variances of the percentage from viable, apoptosis, and necrosis cells are similar.
2. The Independent Samples T-Test results showed viable cells with Sig. $(2$-tailed $)=0.000(<0.025)$, apoptotic cells with Sig. $(2$-tailed $)=$ $0.000(<0.025)$, necrosis cells with Sig. $(2$-tailed $)=0.003(<0.025)$. This suggests that there is a significant difference in the percentage of viable, apoptosis, and necrosis cells between the control and treatment variable.

\section{DISCUSSIONS}

The results of this study showed that HeLa cervical cancer cells death through apoptosis induction.

The apoptosis observation by double staining on the control variables saw a bright green fluorescence cells which showed the living cells and only a few cells seen orange fluorescence or undergo apoptosis. Apoptosis in control cells is normal because apoptosis is also a part of the cell physiological mechanism. In the treatment variable, almost of all the cells die through apoptosis which characterized with yellowish green fluorescence cells. The yellowish green fluorescence indicated the cells undergo DNA fragmentation and chromatin condensation (Figure 1).

Apoptosis in treatment variable still in the early apoptosis. At the late apoptosis, cells will be observed as apoptotic bodies which it colored as orange yellow. Moreover, it also looked an orange-red fluorescence that is indicated the cells undergo necrosis in treatment variable (Figure 1). Necrosis may occur due to environmental factors. Stress occurred during the preparation of cells with double staining which causes the cells die. This cause was also possible.

From the results of cells counting, the cells reduced in viability and increased in a number of apoptotic cells after the cells were treated and incubated for 24 hours. In contrast to the control, after incubation for 24 hours without being treated, the cell viability was much higher and only a few cells undergoing apoptosis (Figure 2). It indicated that the dichloromethane fraction of Garcinia cowa rind has a potential to induce cell death by apoptosis.

The ability of dichloromethane fraction of Garcinia cowa rind in triggering apoptosis expected because of the xanthone compounds in Garcinia cowa. Garcinia cowa contains xanthones in almost of all the parts, such as the fruit, bark, roots, stems, leaves and latex, which showed a strong cytotoxic potential against cancer cells.

Additional studies are required to obtain a more significant reduction in the Bcl-2 gene expression. This can be done with an extended incubation time of cells after treatment with a fraction of Garcinia cowa rind.

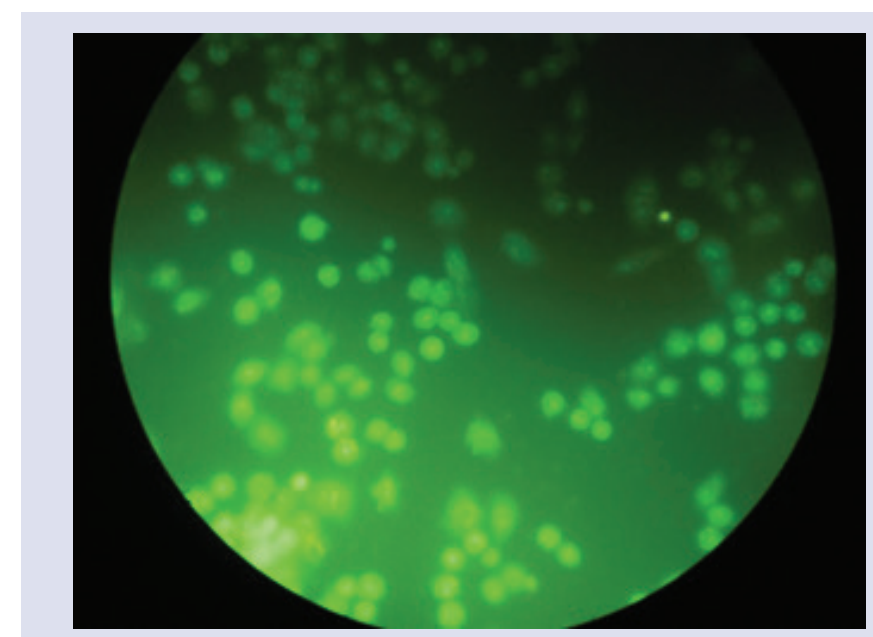

Figure 1: Fluorescence color of cell control after 24 hours incubation. Green fluorescence of viable cells (100x magnification). 


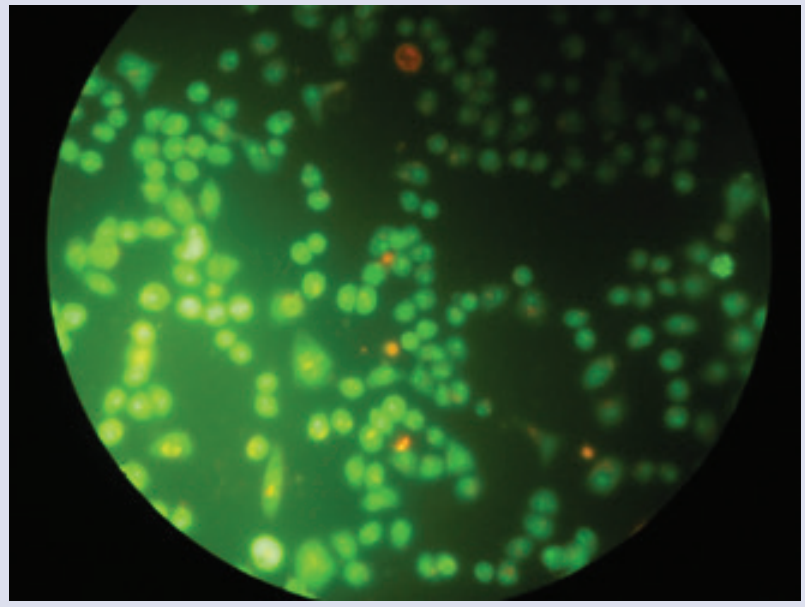

Figure 2: Fluorescence color of the treatment effect fraction dichloromethane rind kandis acid with IC50 $6 \mathrm{mg} / \mathrm{ml}$ against viable cells, apoptosis and necrosis of HeLa cervical cancer cells at $24 \mathrm{~h}$ incubation ) viable cells showed green fluorescence, ( ) cells death by apoptosis showed yellowish green fluorescence, $($ ) cell death by necrosis showed orange to reddish fluorescence (100x magnification).

Further clarification of molecular action also needs to be done, one of them by observing the proapoptotic gene expression, such as Bax, or their interaction (antiapoptotic and proapoptotic, Bcl-2/Bax) in the process of apoptotic induction. Enhancement of the potential of G. cowa as a chemopreventive agent would be very helpful in the development of cancer therapies as well as to minimize the side effects and costs of chemotherapy treatment.

\section{CONCLUSION}

The dichloromethane fraction of G. cowa rind induces apoptosis in HeLa cervical cancer cells

\section{ACKNOWLEDGMENT}

All the authors thank to the Ditlitabmas DIKTI for the financial support under the Program Kreatifitas Mahasiswa Penelitian (PKM-PE) in 2015.

\section{CONFLIC OF INTEREST}

Authors do not have any conflict of interest.

\section{ABBREVIATION USED}

EDTA: Ethylene diamine tetraacetic acid; EtBr: Ethidium bromide; AO: Acridine orange.

\section{REFERENCES}

1. Antoni S, Soerjomataram I, Møller B, Braya F, Jacques Ferlay J. An assessment of GLOBOCAN methods for deriving national estimates of cancer incidence. Bull World Health Organ. 2016:94:174-84. https://doi.org/10.2471/BLT.15.164384; PMid:26966328 PMCid:PMC4773935

2. Yandim MK, Gokbulut AA, Baran Y. Molecular mechanisms of drug resistance and its reversal in cancer. Crit Rev Biotechnol. 2016:36(4):716-26.

3. Delbridge ARD, Grabow S, Andreas Strasser A, Vaux DL. Thirty years of BCL-2: translating cell death discoveries into novel cancer therapies. Nat Rev Cancer. 2016;16(2):99-109. https://doi.org/10.1038/nrc.2015.17; PMid:26822577.

4. Sherr CJ, Bartek J. Cell Cycle-Targeted Cancer Therapies. Annu Rev Cancer Biol. 2017;1:2.1-2.17.

5. Wahyuni FS, Shaari K, Stanslas J, Lajis NH, Dachriyanus. Cytotoxic xanthones from the stem bark of Garcinia cowa Roxb. J Chem Pharm Res 2015;7(1):227-36.

6. Wahyuni FS, Shaari K, Stanslas J, Lajis NH, Hamidi D. Cytotoxic compounds from the leaves of Garcinia cowa Roxb. J Appl Pharm Sci. 2015;5(02):006-011. https://doi.org/10.7324/JAPS.2015.50202.

7. Wahyuni FS, Shaari K, Stanslas J, Lajis NH and Dachriyanus. Cytotoxic Studies of Tetraprenyltoluquinone, A Prenylated Hydroquinone From Garcinia Cowa on H-46-, MCF-7 and DU-145. Int J Pharm Pharm Sci. 2015;7(3):60-63.

8. Wahyuni FS, Hui LS, Stanslas J, Lajis NH and Dachriyanus. Tetraprenyltoluquinone, an Anticancer Compound from Garcinia cowa Roxb Induce Cell Cycle Arrest on H460 Non Small Lung Cancer Cell Line. Int J Pharm Sci Rev Res 2015;32(2):166-68

9. Husni, E, Nahari F, Wirasti Y, Wahyuni FS, Dachriyanus. Cytotoxicity study of ethanol extract of the stem bark of asam kandis (Garcinia cowa Roxb.) on T47D breast cancer cell line. Asian Pacific J Trop Biomed. 2015; 5(3), 249-52. https:// doi.org/10.1016/S2221-1691(15)30013-7.

10. Wahyuni FS, Shaari K, Stanslas J, Lajis NH, \& Dachriyanus. Cytotoxic Xanthones From The Stem Bark of Garcinia cowa Roxb. J Chem Pharm Res. 2015;7(1):227-36.

11. Darzynkiewicz Z, Juan G, Li X, Gorczyca W, Murakami T, Traganos F. Cytometry in Cell Necrobiology: Analysis of Apoptosis and Accidental Cell Death (Necrosis). Cytometry. 1997;27(1):1-20. https://doi.org/10.1002/(SICI)1097-0320(19970101) 27:1<1::AID-CYTO2>3.3.CO;2-X. https://doi.org/10.1002/(SICI)1097-0320(19970101 27:1<1::AID-CYTO2>3.0.CO;2-L.

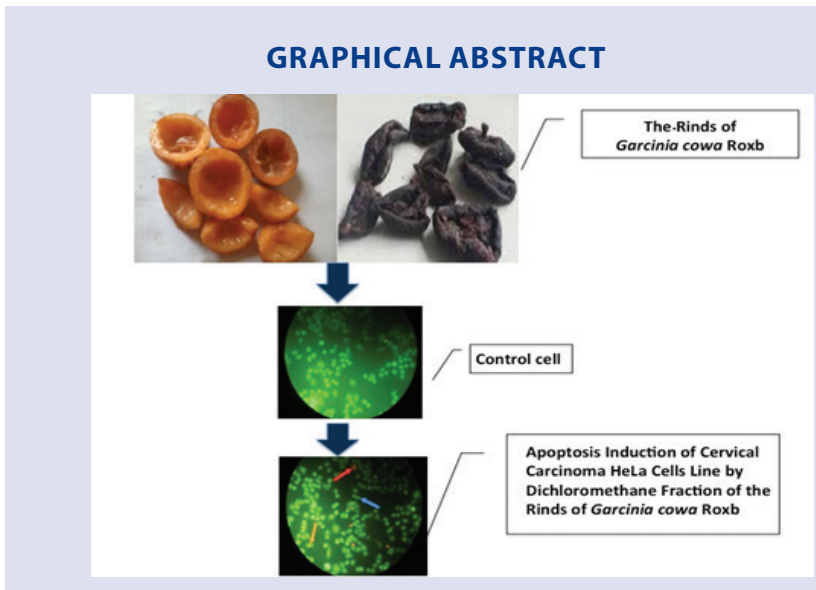

\section{SUMMARY}

The dichloromethane fraction of $G$. cowa rinds provides induces apoptosis in HeLa cervical cancer cells. The average percentage of apoptotic cells was higher in the treated variables $(70.38 \%)$ compared to the control variables (12.26\%). Statistical analysis by Independent Sample T-Test showed apoptosis Sig. (2-tailed) $=0.000(<0.025)$. 


\section{AUTHOR PROFILE}

Fatma Sri Wahyuni: Got her undergraduate degree from Andalas University in 1998 and finished my PhD from University Putra Malaysia in 2010. Her research is in activity studies of Sumatran Plants especially Genus Garcinia

Siska Febria: Is undergraduate student from Andalas University. Her research is sub acute toxicity studies of Garcinia cowa

Dessy Arisanty: Is currently is PhD student from Andalas University. Her research is in Pharmacological activity studies of Sumatran Plants

Cite this article: Wahyuni FS, Febria S, Arisanty D. Apoptosis Induction of Cervical Carcinoma HeLa Cells Line by Dichloromethane Fraction of the Rinds of Garcinia cowa Roxb. Pharmacogn J. 2017;9(4):475-8. 